\title{
紙の蒸気加熱過程における凝縮熱伝達特性に関する実験的研究*
}

\author{
川水努*1, 金子毅*2 \\ 鈴 木 節 夫*3, 鶴 田 隆 治*4
}

\section{Experimental Study on Condensation Heat Transfer Characteristics of Paper in Steam Heating Process}

\author{
Tsutomu KAWAMIZU*5, Takeshi KANEKO, \\ Setsuo SUZUKI and Takaharu TSURUTA \\ ${ }^{* 5}$ Machinery Plant Laboratory, Hiroshima Research and Development Center, \\ Mitsubishi Heavy Industries, LTD., \\ 4-6-22 Kan-on-shin-machi, Nishi-ku, Hiroshima-shi, Hiroshima, 733-8553 Japan
}

\begin{abstract}
The steam heating experiments are carried out with using the handsheet. Effects of suction pressure and permeability of paper on condensation heat transfer characteristics are studied. We measure temperature distribution in the direction of paper thickness and energy absorption in the paper is estimated. Experimental results show that suction pressure enhances the energy absorption in the paper and decreases temperature difference in the paper-thickness direction, and effects of the suction pressure strongly appear in high permeability paper. Experiments also indicate that the absorbed energy rate is decreased with increasing in the steam heating time. In the case of low permeability paper, influence of internal condensation disappears immediately and the conduction dominates the heat transfer in the paper, which indicates that increasing in moisture content prevents steam flow into the paper. On the other hand, in the case of large suction pressure and high permeability paper, results show that the paper is heated rapidly due to the internal condensation.
\end{abstract}

Key Words: Porous Media, Condensation, Mass Transfer, Heat Transfer Enhancement, Experiment, Paper

\section{1. 粕 言}

紙を工業的に大量生産する製紙機械では，植物繊維 を含んだ原料が水分率 $99 \%$ 程度の割合で供給される. 吸引工程, 圧控工程, 乾燥工程により, 原料濃度が高 められ，最終的には水分率 $5 \%$ 程度の状態となる. 木 ットプレッシングは, 紙の温度を高め, 紙中水分の粘 性を低くすることにより，圧擢時の脱水量を増加させ る手法である. 生産速度向上, 乾燥工程の負荷低减, ならびに機長短縮を狙いとして適用が推進されている. このホットプレッシングを実施する目的で紙の蒸気加 熱が実施されており，加熱能力およひ効率向上を狙っ てサクションボックスと呼ばれる負圧室を蒸気供給部 の反対側に設置し, 紙内部一の蒸気流入を促進してい

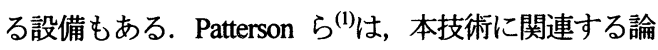
文のレビューを行い，現象の支配因子が解明されてい ないことを指摘した. そして, 彼らは蒸気供給部とサ

* 原稿受付 2006 年 4 月 17 日.

*1 正員, 三菱重工業(株)技術本部(画733-8553 広島市西区観 音新町 4-6-22).

*2 学生員, 九州工業大学大学院工学研究科 (业) 804-8550 北九 州市戸畑区仙水町 1-1) [現：三菱重工業(株)技術本部]

*3 三菱重工業(株)紙・印刷機械事業部.

*4 正員, 九州工業大学工学部.

E-mail : tsutomu_kawamizu@mhi.co.jp
クションボックスを固定し, 紙をそこへ搬送する方式 の蒸気加熱実験を実施し，その加熱特性を評価した(2) (4). 紙の透過率が入熱量を支配することを明らかにし たが，蒸気加熱にともなう水分率の増加などがその加 熱特性におよぼす影響については評価されていない. また，彼らの実験では紙の走行にともなう蒸気加熱部 への不凝縮性ガスの流入とサクション圧力変動の影響 が懸念される. 本研究では, 不凝縮性ガスの流入, サ クション圧力変動の影響を極力排除した実験を実施し, 紙の蒸気加熱特性に対するサクション圧力, 透過率の 影響を評価するとともに，蒸気加熱過程で生じる水分 率の増加などが加熱特性におよぼす影響を実験的に明 らかにした。

\section{2. おもな記号}

$C_{p}, C_{p f}$ : 水比熱 瀻維比熱 $\left.(=1300) \quad \mathrm{J} / \mathrm{kgK}\right)$

$$
D a: \text { ダルンー数 }
$$

$h_{\mathrm{g}}:$ 凝縮替熱

$k:$ 透過率

$\mathrm{J} / \mathrm{kg}$

$L:$ 代表法 $\left(z_{p}\right)$

$\mathrm{m}^{2}$

$m_{l}, m_{f}$ : 湿紙内の水分質量, 䋊維質量

$\mathrm{m}$

$\Delta P$ : 差压 $\mathrm{kg} / \mathrm{m}^{2}$

$\mathrm{Pa}$ 


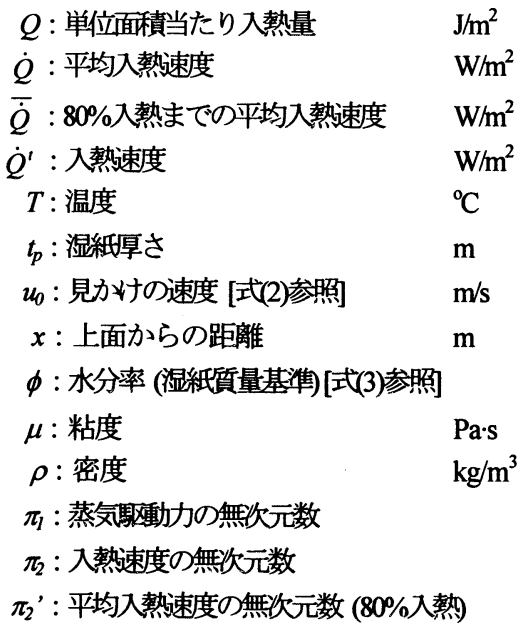
添え字

$$
\begin{aligned}
& g: \text { ガス } \\
& i: \text { 初期値 } \\
& v: \text { 蒸気 }
\end{aligned}
$$

\section{3. 実検装晴および実硂方法}

供試湿紙に透過率の異なる 2 種類の紙(新聞原料の 手㭽き紙(以下新聞紙)，上質紙原料の手漉き紙(以下上

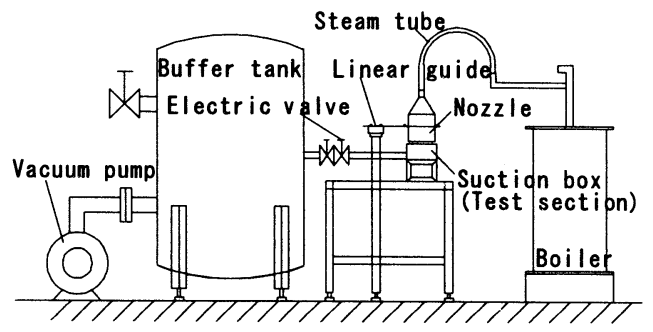

Fig.1 Experimental apparatus Thermo couple Thin paper

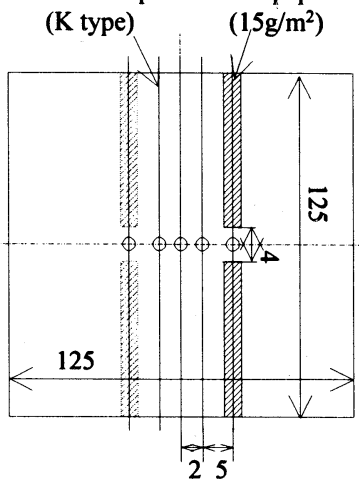

1 Layer $\left(25 \mathrm{~g} / \mathrm{m}^{2}, 50 \mathrm{~g} / \mathrm{m}^{2}\right)$

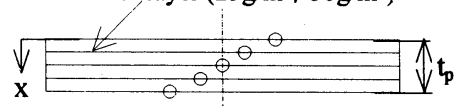

Fig.2 Detail of test piece
質紙))を用いて，図 1 に示す実験装置で蒸気加熱実験 を実施した. 絶乾質量 $100 \mathrm{~g} / \mathrm{m}^{2}, 200 \mathrm{~g} / \mathrm{m}^{2}$ の供試湿紙を 幅 $125 \mathrm{~mm}$, 長さ $125 \mathrm{~mm}$, 絶乾質量 $25 \mathrm{~g} / \mathrm{m}^{2}$ の手溏き紙 を重ねて作成した．絶乾質量は，紙を $110^{\circ} \mathrm{C}$ にして 2 時間空気中で乾燥させて測定される質量である. 図 2 には供試湿紙の形状ならびに熱電対での温度測定位置 を示す． 線径 $25 \mu \mathrm{m}$ の 型熱電対(被覆無し)を湿紙厚 さ方向 $x / t_{p}=0.0,0.25,0.5,0.75,1.0$ の位置に設置し 厚さ方向の温度分布を測定した. $x$ は湿紙上面からの 距離， $t_{p}$ は湿紙厚さを示す. 上面，下面に設置する熱 電対は, 約 $15 \mathrm{~g} / \mathrm{m}^{2}$ の薄紙を $2 \mathrm{~mm}$ 幅に切り, 熱電対の 測温接点と前後 $2 \mathrm{~mm}$ ずつあけ, 薄紙と湿紙とを張り 合わせることで固定した. 供試湿紙は $1.37 \mathrm{MPa}$ の面圧 で 5 分間プレスされ, 各層ならびに上面・下面の熱電 対が密着・固定されている.

供試湿紙は, 水分率調整後, サクションボックス上 に設置される(図 1). 供試湿紙の水分率は, 設置作業中 と蒸気加熱前の初期サクション負荷時に低下するため, 予め校正曲線を取得し，設置前に水分减少量を考慮し た水分率を与えた. 初期サクション負荷後, 湿紙厚さ 方向に水分分布が生じていないことを実験により確認 している.

図3にはサクションボックス上での供試湿紙の設置 状態を示す. サクションボックス上面中央に幅 $50 \mathrm{~mm}$, 長さ $50 \mathrm{~mm}$ の開口部が有り,ここにサクションが作用 する. 供試湿紙の変形を防止する目的で下面に多孔板 とフェルトを設置した. フェルトは紙に対して十分透 過率の大きいものを用いている．供試湿紙へサクショ
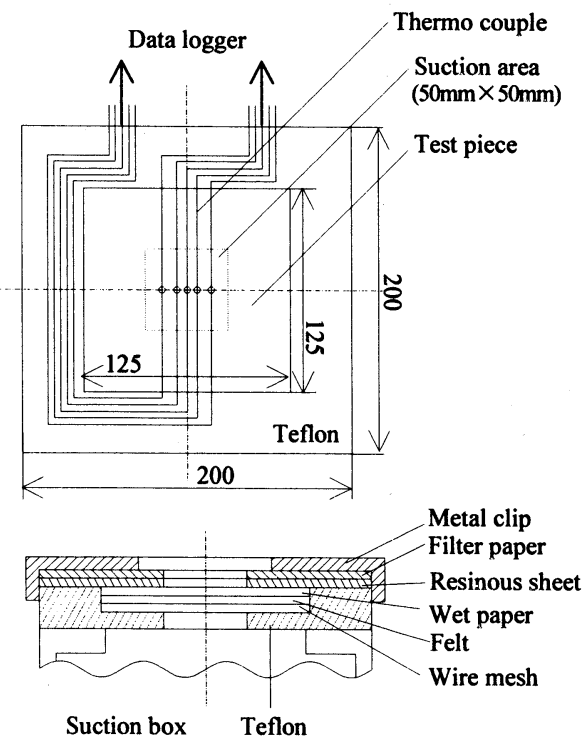

Fig.3 Schematic of test section 
ン作用部以外から蒸気・空気が流入するのを防ぐため, 樹脂製シートを設置し，その上にテストセクション周 囲で生じた凝縮水の流入を防ぐための濾紙を置いて金 属製のカバーで固定した. 外部に導出した熱電対はテ ープで絶縁・固定し, サンプリング速度 $200 \mathrm{~Hz}$ で湿紙 内温度分布の測定が行われた. あわせて供給蒸気温度, サクションボックス内圧力の測定も実施した.

ボイラーで発生した蒸気は(図 1), 配管を通って蒸 気ノズル $(100 \mathrm{~mm} \times 100 \mathrm{~mm})$ から湿紙上面一供給される. 蒸気ノズル内部には整流板が設置されており，一様流 が形成されている. 蒸気ノズルは実験時のみの蒸気加 熱を実施するため, リニアガイド上を図 1 の紙面方向 に約 $500 \mathrm{~mm} / \mathrm{s}$ で移動する. また, 供給蒸気流量は, 蒸 気加熱により消費される蒸気量よりも十分に多い $9.0 \mathrm{~kg} / \mathrm{hr}$ とした. 配管内での蒸気の凝縮を防ぐため, 配管にヒーターを巻き，その外周を断熱材で覆った. これにより, 供給蒸気は $103 \sim 110^{\circ} \mathrm{C}$ 過熱蒸気となっ ている.

サクションボックスは(図 1), 真空ポンプを用いて 予めバッファタンク内を設定圧力まで減圧し, 実験時 に電磁弁を開くことで負圧にされる. バッファタンク は蒸気加熱実験中(約 30s)にサクションボックス内圧 力が一定となるよう十分大きな容積のものを使用した.

実験は供給蒸気の温度が安定したことを確認した あと, バッファタンクを目標圧力に減圧して電磁弁を 開き, 約 $10 \mathrm{~s}$ 後にサクションボックス内が目標圧力と なった時点で, 蒸気ノズルを湿紙上部に移動して実施 した. 加熱前にサクションを作用させることにより, 湿紙内に定常圧力分布が形成された状態からの蒸気加

\section{熱実験が行われる.}

表 1 に実験条件を示す. 湿紙への蒸気流入量の違い が凝縮熱云達特性におよぼす影響を評価することを目 的として湿紙の透過率(紙種 : 新聞紙，上質紙)と湿紙 厚さ(絶乾質量：上質紙 $100 \mathrm{~g} / \mathrm{m}^{2}, 200 \mathrm{~g} / \mathrm{m}^{2}$ )を供試湿紙 の実験パラメータとした. 装置側の実験パラメータは サクション圧力とした. なお, 初期水分率は製紙機械 においてホットプレッシングが実施される水分率を考 慮して 55\%とした.

\section{4. 維の透過事と紙厚}

サクション作用時は, 流入した蒸気が湿紙内部で疑 縮するので, 入熱速度は蒸気流入量によって変化する ことになる. 透過率は蒸気流入量に影響をおよぼす重 要な值であり, 湿紙への入熱速度を決定するパラメー 夕の一つとなる. 本実験で適用する差圧においては, 湿紙中の気体の流れは粘性支配であり, ダルシ一則に 従うと考えられる. このことから, 次式を用いて湿紙 の透過率 $k$ を評価した.

$$
k=\frac{\mu_{g} u_{0} t_{p}}{\Delta P}
$$

ここで, $u_{0}$ は気体の見かけの速度であり, 次式より求 める.

$$
u_{0}=\frac{\text { 通過気体体積流量 }}{\text { 紙の面積 }}
$$

蒸気加熱実験に用いた紙と同一の手漉き紙を用い て, 水分率と透過率, 水分率と湿紙厚さの関係を測定 した. 図 4 に新聞紙と上質紙の透過率測定結果を, 図 5 には絶乾質量 $50 \mathrm{~g} / \mathrm{m}^{2}$ での水分率と湿紙厚さ $t_{p}$ の関倸

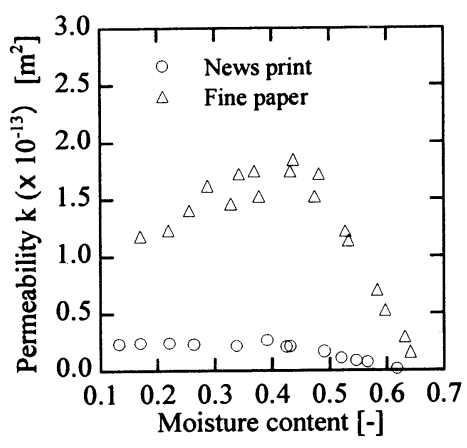

Fig.4 Permeability of paper

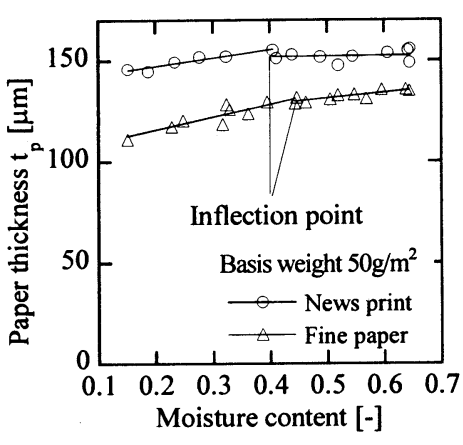

Fig.5 Paper thickness

Tablel Experimental conditions

\begin{tabular}{c|cccc}
\hline Grade & $\begin{array}{c}\text { Basis weight } \\
{\left[\mathrm{g} / \mathrm{m}^{2}\right]}\end{array}$ & $\begin{array}{c}\text { Number of } \\
\text { thermo couples }\end{array}$ & $\begin{array}{c}\text { Initial moisture } \\
\text { content } \phi_{i}[-]\end{array}$ & $\begin{array}{c}\text { Suction pressure } \\
(\text { Gauge })[\mathrm{kPa}]\end{array}$ \\
\hline News print & 100 & 5 & 0.55 & $0,-25,-46$ \\
\hline \multirow{2}{*}{ Fine paper } & 100 & 5 & 0.55 & $0,-5,-15,-25$ \\
\cline { 2 - 6 } & 200 & 5 & 0.55 & $0,-5,-15,-25$ \\
\hline
\end{tabular}


を示す.透過率は与えられた差圧 $\Delta P$ における通過空気 流量を測定し，湿紙厚さを用いて式(1)(2)から求めた. 紙の通過気体体積流量, 厚さ計測法は JIS ${ }^{(5)}$ に規定され ており，恒温恒湿の室内で計測を行った．また，本報 で用いた水分率は次式で定義される.

$$
\text { 水分率 } \phi=\frac{\text { 湿紙質量一絶乾質量 }}{\text { 湿紙質量 }}
$$

紙は植物䋊維から構成されており, 水を吸収しやす く, 水分率により厚さが変化する(図 5). 上質紙の場合, 水分率44\%付近までは水分率の増加にともない厚さが 厚くなるが，水分率 44\%以降はその勾配がゆるやかに なる. 水分率 44\%までは供給された水が繊維内に取り 込まれ, 繊維が膨閏して湿紙が厚くなるのに対し, 44\% 以上の水分領域では䋐維内に吸収されず，供給された 水は繊維間の空隙内に保持されるようになるためと考 えられる.この繊維内に水を吸収できなくなる水分率

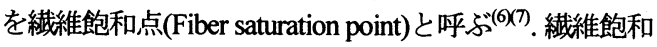
点までは繊維が膨潤し, 繊維間の空隙が増すため, 図 4 に示されるように上質紙では水分率の増加にともな い透過率が上昇する. 一方, 新聞紙では繊維飽和点以 下の領域で湿紙厚さの変化は少なく(図 5), 透過率もほ とんど変化していない(図 4). 緎維飽和点以上では空隙 内に水が保持され，ガスの流動が妨げられるために上 質紙，新聞紙とも透過率は水分率の増加によって低下 する. 緘維飽和点以下の領域で, 透過率ならびに厚さ に対する水分率の影響が 2 種の紙で異なっているのは, 紙を構成する植物繊維等の特性の違いに起因するもの であると考えられる. 表 2 に実験に用いた新聞紙, 上 質紙の湿紙厚さ, バルク密度, バルク比熱, バルクの 熱伝導率, 㵶維飽和点および透過率を示す. 実験に用 いた 2 種類の紙では，透過率に大きな違いがあるのが 特徵である. 厚さの差は小さくバルク密度の差も小さ い. バルクの熱伝導率は初期水分率 $55 \%$ の領域では水 の熱伝導率が支配的であり, 密度差も小さいことから 紙種による差異はほとんど無いと考えられる.ここで は, Nederveen の測定結果 ${ }^{(8)}$ を定式化した式(9)から値を 予測したものを示した. 初期水分率 $55 \%$ で蒸気加熱実
験を行うため, 水分率は䋊維飽和点以上の領域にあり， 蒸気加熱にともなう水分率の増加によって透過率は減 少する.

\section{5. 実験結果と考察}

5.1 入熱量評価方法 蒸気加熱される湿紙の温 度変化を測定し，その測定值を用いて，以下に示す方 法で入熱速度, 入熱量の評価を実施した。

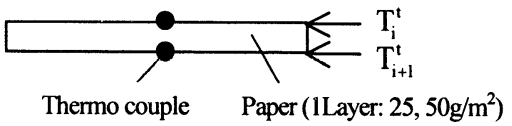

Fig.6 Calculation method of absorbed energy

供試湿紙 1 層の拡大図を図 6 に示す. 時刻 $t$ におけ る湿紙の上面, 下面, それぞれの温度を $T_{i}^{\prime}, T_{i+1}^{\prime}$ とし, この層の代表温度 $\bar{T}_{i}^{t}$ を次式であらわす.

$$
\bar{T}_{i}^{\prime}=\left(T_{i}^{t}+T_{i+1}^{t}\right) / 2
$$

$\Delta$ 時間内における入熱量 $Q_{i}^{\prime}\left[\mathrm{J} / \mathrm{m}^{2}\right]$ は，

$$
Q_{i}^{\prime}=\left(C_{p_{l}} m_{l}+C_{p_{f}} m_{f}\right)\left(\bar{T}_{i}^{t+\Delta t}-\bar{T}_{i}^{\prime}\right)
$$

であらわされる.ここで水分質量 $m_{l}$ は初期水分率にお ける値を用いた. $m_{f}$ は瀻維質量, $C_{p l}$ は水の比熱, $C_{p f}$ は繊維の比熱である. $\Delta t$ 時間内における湿紙全体の入 熱量 $Q^{t}\left[\mathrm{~J} / \mathrm{m}^{2}\right]$, 各層に対して求めた $Q_{i}^{t}$ 紙の積層枚 数分だけ積分して求められる.また, 入熱速度 $\dot{Q}^{t}\left[\mathrm{~W} / \mathrm{m}^{2}\right]$ は $Q^{t}$ をオで除せばよい.

$$
Q^{t}=\int_{x=0}^{t} Q_{x}^{t} d x=\sum_{i=1}^{n} Q_{i}^{t}
$$

$n:$ 湿紙積層枚数

$$
\dot{Q}^{t}=\int_{x=0}^{t_{\rho}} Q_{x}^{\prime} d x / \Delta t=Q^{\prime} / \Delta t
$$

加熱開始から時刻 $t$ までの全入熱量 $Q$ は, $Q^{t}$ を時間積 分することで得られ平均入熱速度 $\dot{Q}$ は $Q$ を $t$ で除すこ とで得られる.

$$
\begin{aligned}
& Q=\int_{0}^{t} Q^{t} d t=\sum_{t=0}^{t} Q^{t} \\
& \dot{Q}=Q / t
\end{aligned}
$$

Table2 Characteristics of paper

\begin{tabular}{c|c|c}
\hline Grade & News print & Fine paper \\
\hline Basis weight $\left[\mathrm{g} / \mathrm{m}^{2}\right]$ & 100 & 100,200 \\
\hline Paper thickness $t_{p}[\mu \mathrm{m}], \phi=0.55$ & $300\left(100\left[\mathrm{~g} / \mathrm{m}^{2}\right]\right)$ & $\begin{array}{c}280\left(100\left[\mathrm{~g} / \mathrm{m}^{2}\right]\right) \\
560\left(200\left[\mathrm{~g} / \mathrm{m}^{2}\right]\right)\end{array}$ \\
\hline Density (Bulk) $\left[\mathrm{kg} / \mathrm{m}^{3}\right], \phi=0.55$ & 740 & 793 \\
\hline Specific heat (Bulk) $[\mathrm{J} /(\mathrm{kg} \cdot \mathrm{K})], \phi=0.55$ & 2893 & 2893 \\
\hline Thermal conductivity (Bulk) $[\mathrm{W} /(\mathrm{m} \cdot \mathrm{K})], \phi=0.55$ & \multicolumn{2}{|c}{0.456} \\
\hline Fiber saturation point $\phi$ & 0.383 & 0.438 \\
\hline Permeability $k\left[\mathrm{~m}^{2}\right], \phi=0.55$ & $8.43 \times 10^{-15}$ & $1.02 \times 10^{-13}$ \\
\hline
\end{tabular}


$5 \cdot 2$ 実験結果 図 7 に新聞紙，上質紙のサクシ ヨン圧力(ゲージ圧)0，-25kPaにおける温度分布の実測 值と入熱速度 $\dot{Q}^{t}$ の評価値を示す. サクションが作用し ない，すなわち熱伝導のみで湿紙内部に熱が伝えられ る場合[(a),(c)], 温度分布, 入熱速度に紙種による違い がないことが示された. サクション圧力-25kPa を作用 させた場合[(b),(d)], サクションが作用しない実験に比 べて，加熱開始から下面が温度上昇を開始するまでの
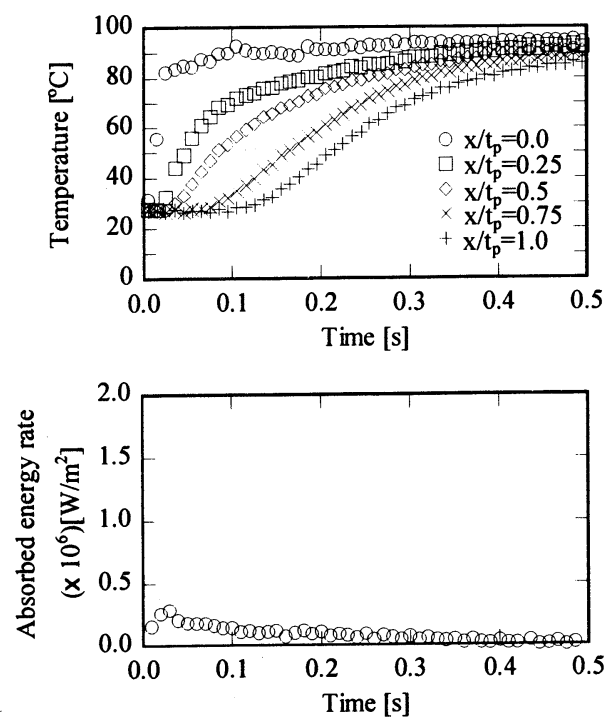

(a) News print, $100 \mathrm{~g} / \mathrm{m}^{2}, 0 \mathrm{kPa}$
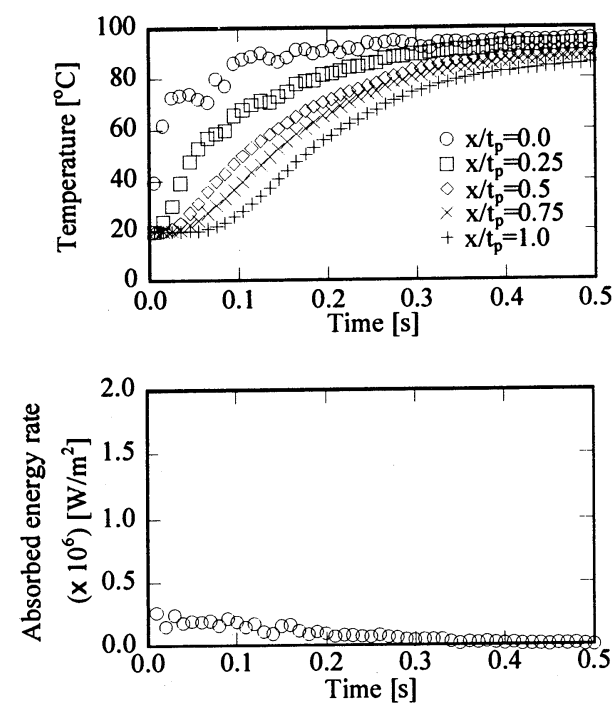

(c) Fine paper, $100 \mathrm{~g} / \mathrm{m}^{2}, 0 \mathrm{kPa}$
時間遅れが短くなった．また，加熱開始 $0.1 \mathrm{~s}$ 後の紙厚 方向の温度差が小さくなっている. サクション作用時 の湿紙の温度は, 蒸気供給面である上面側から順次上 昇しており，下面の温度上昇が始まる前に厚さ方向 $x / t_{p}=0.25$ 位置の温度はほぼ定常値に近い值に達してい る. 湿紙内に流入した蒸気は, 各位置の温度を圧力に 対応した平衡温度まで上昇させつつ，上面から下面に 向かって凝縮領域を拡大させていることを示すもので
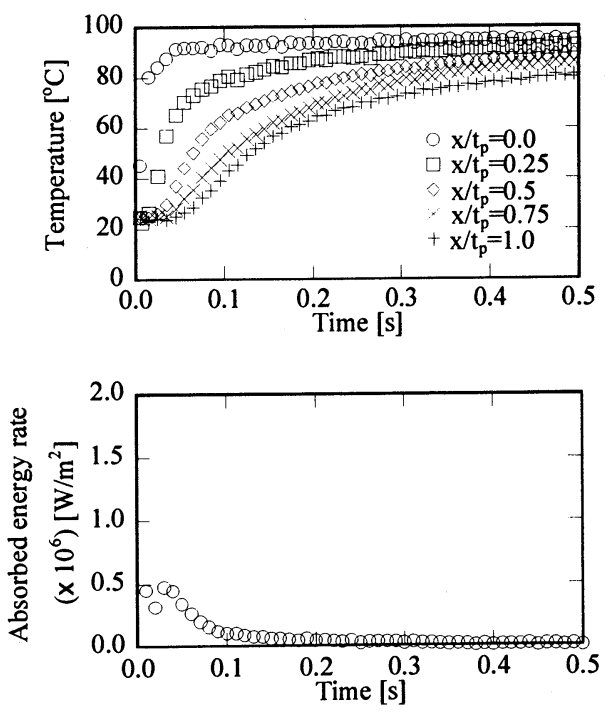

(b) News print, $100 \mathrm{~g} / \mathrm{m}^{2},-25 \mathrm{kPa}$
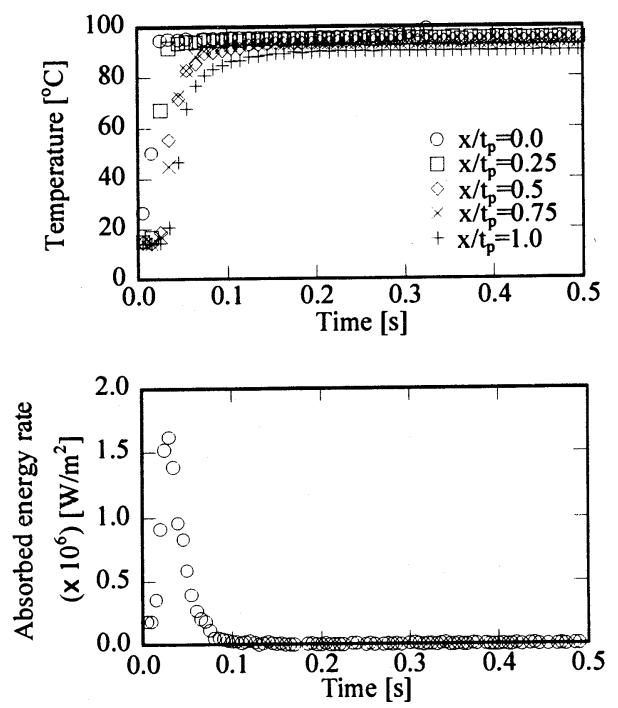

(d) Fine paper, $100 \mathrm{~g} / \mathrm{m}^{2},-25 \mathrm{kPa}$

Fig.7 Temperature profile and absorbed energy rate 
ある. そして，サクション作用時の定常状態下での上 質紙の温度は, 紙厚方向各位置での圧力に対応した蒸 気の平衡温度となっている. 図7(d)において加熱開始 $0.5 \mathrm{~s}$ 後の湿紙温度は, $x / t_{p}=1.0$ の位置でサクション圧力 $-25 \mathrm{kPa}$ に対応した蒸気の平衡温度 $92.2^{\circ} \mathrm{C}$ と実測值がほ ぼ等しい. 入熱速度は, 加熱開始直後に最大值があら われ，その後時間とともに低下している. 加熱が進む につれ湿紙内部で凝縮にともなう水が増え，水分率が 上昇して透過率が低下することおよび圧力損失が発生 する凝縮領域が拡大することに起因するものである. また, 新聞紙と上質紙にサクション圧力-25kPa を作用 させた場合[(b),(d)], 入熱速度の最大値は新聞紙より上 質紙の方が約 3 倍大きい，上質紙の透過率が新聞紙に 比べて大きいためである. 新聞紙では, 加熱開始後 $0.1 \mathrm{~s}$ 付近から入熱速度はサクションが作用しない場合の值 とほほ等しくなる. 新聞紙の場合, $0.1 \mathrm{~s}$ 以降は蒸気流 入による加熱の促進効果が小さく, 湿紙内部はサクシ ヨンの作用しない場合と同様に熱伝導のみで上面から 加熱されていると考えられる，一方，上質紙では，湿 紙全体が定常温度に達するまで入熱速度が速い，蒸気 が下面付近まで到達し，下面付近も蒸気によって直接 凝縮加熱されているためと考えられる.このことから， 同一サクション圧力を作用させた場合, 透過率の高い 上質紙の方がサクションの効果が高いことが明らかに なった.

$5 \cdot 3$ サクション压カと入熱量 図 8 に加熱開始 から 30,50,100ms までの湿紙への入熱量 $Q$ とサクシ ヨン圧力の関係を示す. 前述したようにサクションが 作用しない場合，各時間において新聞紙と上質紙の入 熱量はほぼ等しく，紙種による差異はない，サクショ ンを作用させた場合，新聞紙，上質紙ともにサクショ ン圧力の増加にともなって湿紙一の入熱量が上昇する. サクション圧力に対する入熱量の増加は，新聞紙より 上質紙の方が大きい，また，新聞紙に上質紙の約 10 倍のサクション圧力を作用させると(新聞紙 : $-46 \mathrm{kPa}$, 上質紙 : $-5 \mathrm{kPa}), 30 \mathrm{~ms}, 50 \mathrm{~ms}$ 後での入熱量はほぼ等し いが, $100 \mathrm{~ms}$ 後においては上質紙のほうが多い. 初期 水分率 55\%における上質紙の透過率が新聞紙より約 10 倍大きいため(表 2), 新聞紙に作用するサクション 圧力が約 10 倍上質紙に対して大きい場合, 加熱開始直 後 $(30,50 \mathrm{~ms})$ では新聞紙と上質紙で蒸気流入量・入熱量 がほぼ等しくなる．その後, 水分率が上昇して透過率 が低下する際に，新聞紙は上質紙より水分率増加によ る透過率の低下割合が大きく, 蒸気流入量の減少割合 も高いため $100 \mathrm{~ms}$ 後の入熱量が少なくなったと推定さ れる.

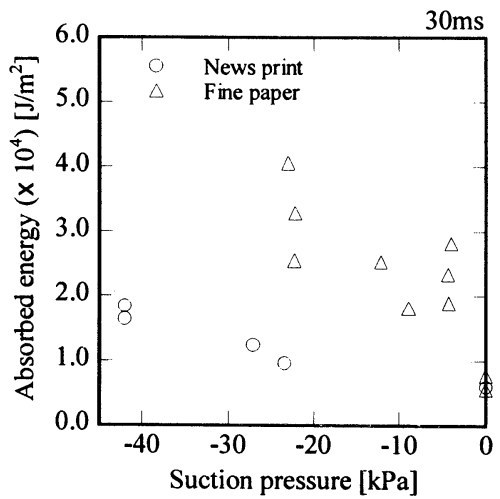

(a) $\mathrm{t}=30 \mathrm{~ms}$

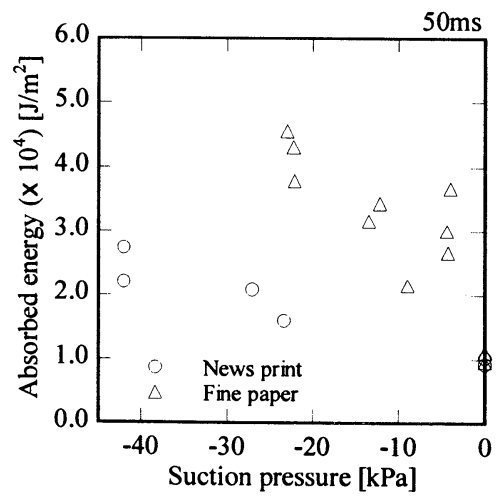

(b) $\mathrm{t}=50 \mathrm{~ms}$

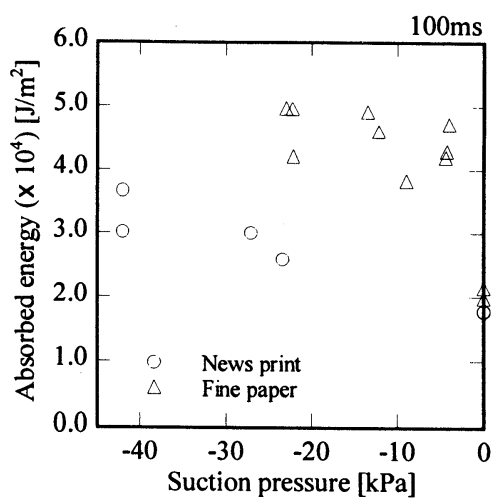

(c) $\mathfrak{t}=100 \mathrm{~ms}$

Fig.8 Relation between suction pressure and absorbed energy $\left(100 \mathrm{~g} / \mathrm{m}^{2}\right)$

5.4 無次元数による実倹拮果の整理 以下に示 す無次元数を用いて実験結果の整理を行った. 本無次

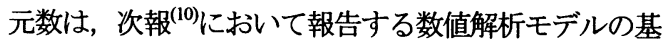
礎式から導出されたものである. 詳細については解析 結果とあわせて次報で報告を行う。 


$$
\begin{aligned}
& D a \cdot \pi_{1}=\left(\frac{k_{i}}{L^{2}}\right)\left(\frac{\rho_{v} L^{2} \Delta P}{\mu_{v}{ }^{2}}\right) \\
& \pi_{2}=\frac{L \dot{Q}^{\prime}}{\mu_{\nu} h_{f g}} \\
& \pi_{2}{ }^{\prime}=\frac{L \dot{Q}}{\mu_{v} h_{f g}}
\end{aligned}
$$

$D a$ 数は透過率の無次元数で, 紙の通気抵抗をあら わし， $\pi_{l}$ は差圧 $\Delta P($ 大気圧一サクション圧力)による多 孔質体内での蒸気駆動力をあらわす. $k_{i}$ は初期透過率, $L$ は代表寸法(=湿紙厚さ $\left.t_{p}\right)$ である. ここで $D a$ 数と $\pi_{l}$ の積は(式(10)), 湿紙の蒸気流入に対する抵抗力之駆動 力の比となり, 蒸気の流入のしやすさを示す無次元数 となる. $\pi_{2}$ (式(11))は湿紙への入熱速度をあらわす無次 元数である. ホットプレッシングの脱水促進効果なら びに紙品質への影響が実験的に評価されている高温側 の温度領域 ${ }^{(1)}\left(80^{\circ} \mathrm{C}\right.$ 以上)を考慮して $80 \%$ 入熱までの平 均入熱速度をあらわす無次元数 $\pi_{2}{ }^{\prime}$ を式(12)で定義し た. $\overline{\dot{Q}}$ は湿紙を定常温度まで昇温するために必要な熱 量の $80 \%$ が入熱するまでの平均入熱速度, $h_{\mathfrak{g}}$ は凝縮潜

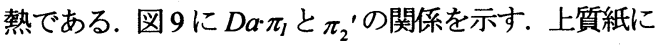
ついては, 絶乾質量 $200 \mathrm{~g} / \mathrm{m}^{2}$ での実験結果もあわせて 図中に示した. サクション圧力は, 新聞紙 $0,-25,-46 \mathrm{kPa}$, 上質紙 $0,-5,-15,-25 \mathrm{kPa}$ である.

$D a \cdot \pi_{l}$ が大きいほど平均入熱速度は速くなる. $D a \cdot \pi_{l}$ が大きくなることで, 湿紙内一の蒸気流入量が増加す るためである. 新聞紙は上質紙に比べて $D a$ 数が小さ く, サクション圧力を大きくしても $D a \cdot \pi_{l}$ が上質紙ほ ど大きくならないことから，サクションの効果を得に くいことがわかる. 新聞紙-46kPa と上質紙-5kPa では $D a \cdot \pi_{1}$ がほぼ等しく(1.1 1.2), 80\%入熱までの平均入熱

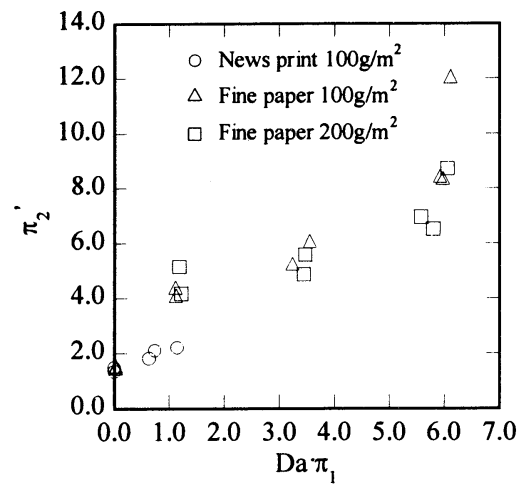

Fig.9 Relation between $\mathrm{Da} \cdot \pi_{1}$ and $\pi_{2}$ '
速度の無次元数 $\pi_{2}{ }^{\prime}$ を比較すると, 図 8 で示した加熱 $100 \mathrm{~ms}$ 後までの入熱量と同様に上質紙のほうが速い. これは前述したように加熱の進行とともに湿紙内部の 水分率が上昇した際の，透過率の低下が上質紙に比べ て新聞紙のほうが大きいためであると推測される。 ま た，上質紙，絶乾質量 $100 \mathrm{~g} / \mathrm{m}^{2} ， 200 \mathrm{~g} / \mathrm{m}^{2}$ に対する無次 元数整理結果から同一の紙種においては, 絶乾質量に かかわらずサクション作用時の平均入熱速度 $\pi_{2}{ }^{2}$ が $D a \cdot \pi_{1}$ を用いて整理できることが図 9 に示されている.

湿紙内への蒸気の流入のしやすさをあらわす無次 元数 $D a \cdot \pi_{I}$ がサクションを用いることによる入熱速度 向上効果の指標の 1 つとなることが明らかになった.

\section{6. 結}

透過率の異なる2種類の紙を用いて蒸気加熱実験を 実施し, 紙厚方向の温度分布の変化を測定した. また, 温度変化から入熱速度, 入熱量を求め, 以下のことが わかった.

（1） サクションを作用させると入熱速度が上昇 し, 同一サクション圧力では, 透過率が高いほ ど入熱速度が速い。

(2) 今回の実験に用いた新聞紙のように透過率 が低い紙では, サクション作用時において, 加 熱開始初期のみ，蒸気流入にともなう内部での 凝縮加熱が行われ，その後は熱伝導による加熱 へと移行する.

（3）今回の実験に用いた上質紙のように透過率 が高い紙では，サクション作用時において，紙 が蒸気加熱時の定常温度に達するまで蒸気流 入にともなう内部凝縮で加熱される.

（4）サクションを作用させたとき，入熱速度は加 熱開始直後に最大值を示し, その後, 時間の経 過とともに低下する. 加熱が進むにつれて, 紙 内部の水分率が増加して透過率が低下寸ること, および圧力損失が発生する凝樎領域が拡大する ためである.

(5) 湿紙内への蒸気の流入のしやすさをあらわす 無次元数 $D a \cdot \pi_{1}$ がサクションを用いることによ る入熱速度向上効果の指標の 1 つとなる.

本研究の遂行にあたり熱心に協力頂いた九州工業 大学大学院生 平野 宏君, 学部 4 年生 長井 博之君(当 時にに心ら謝意の意を表す。 


\section{考文献}

(1) Patterson, T. and Iwamasa, J., Review of Web Heating and Wet Pressing Literature, TAPPI 99 Proceedings, (1999), pp. 1255-1278.

(2) Patterson, T. et al., An Apparatus for the evaluation of web-heating technologies - Development, capabilities, preliminary results, and potential uses, TAPPI JOURNAL MARCH 1996, pp. 269-278.

(3) Patterson, T. and Iwamasa, J., Steambox Comparator Experiments: Apparatus Validation and Investigation of Steambox Performance, 1999 TAPPI Engineering/Process and Product Quality \& Trade Fair, pp. 621-635.

(4) Patterson, T., An investigation of factors affecting steambox heating effectiveness, TAPPI JOURNAL SEPTEMBER 2002, pp. 8-12.

(5) Japan Industrial Standard, P 8117, P 8118.

(6) Kadoya, T. et al., SCIENCE OF PAPERMAKING, (1982), p. 94, CHUGAI SANGYO CHOSAKAI.
(7) Karlsson, M., Paper making Part2, Drying, (2000), pp. 54-83, Fapet Oy, Finland.

(8) Nederveen, C.J. and Finken, J.G., THERMAL CONDUCTIVITY MEASUREMENT ON WET PAPER SAMPLES AT HIGH TEMPERATURES, DRYING TECHNOLOGY, Vol.10 (1) (1992), pp. 189-198.

(9) Hoshi, Y. et al., Prediction of Temperature and Moisture Content Profiles of Paper in Drying Process, Transactions of the Japan Society of Mechanical Engineers, Series B, Vol.64, No.625 (1998), pp. 281-288.

(10) Kawamizu, T. et al., Analytical Study on Condensation Heat Transfer Characteristics of Paper in Steam Heating Process, Transactions of the Japan Society of Mechanical Engineers, Series B, Vol.73, No.727 (2007), pp. 823-830. 